\title{
GUIDING THE INCUBATION OF SMES
}

\section{Carutasu, G.; Turcoiu, T.; Botezatu, C.P. \& Botezatu, C.}

Abstract: The paper present the activity of two incubation centers, dedicated to SMEs', where, in their first stage of life, the incubated firms are sustained in their activity by the incubation center, by low costs services. Furthermore, the European and national comparatively situation for Incubators, is presented, generally being localised in universities, scientific parks or other public or private facilities. Another good point of these practices is the implementation of an information system, used in common by all incubated firms, al low price and also still used after the incubation period. This system has three-tier architecture: data, information and knowledge level, being also a client-server solution, being scalable and personalised by SMEs, needs and also is fed with real data, provided by incubated firms, transforming them, by aggregate functions in information and in the upper level, in knowledge. In conclusion, this paper present a set of tested practices in SMEs' incubators.

Key words: business incubation, tele-working, management, client-server architecture
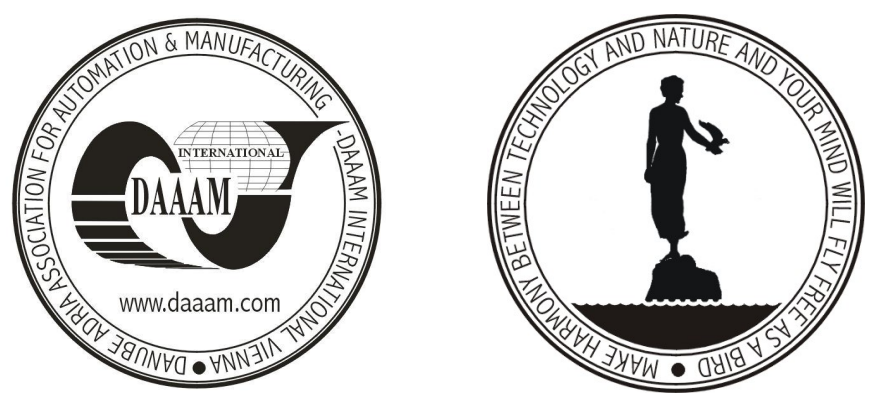

Authors' data: PhD. Eng. Carutasu, G[eorge $]^{*}$; Prof. PhD. Eng. Turcoiu, T[iti]**; Prof. PhD. Ec. Botezatu, C[ornelia] P[aulina]*; PhD. Math. Botezatu, C[ezar]*, * Romanian-American University, Bucharest, Romania, ** University POLITEHNICA of Bucharest, Bucharest, Romania, george@mix.mmi.pub.ro, turcoiu@utis.cpru.pub.ro, cbotezatu@rau.ro, cbotezatu@rau.ro

This Publication has to be referred as: Carutasu, G.; Turcoiu, T.; Botezatu, C.P. \& Botezatu, C. (2007). Guiding the incubation of SMEs, Chapter 33 in DAAAM International Scientific Book 2007, B. Katalinic (Ed.), Published by DAAAM International, ISBN 3-901509-60-7, ISSN 1726-9687, Vienna, Austria

DOI: $10.2507 /$ daaam.scibook.2007.33 